\title{
CARCASS AND BREAST MEAT QUALITY OF BROILERS FEED WITH EXTRUDED CORN
}

\author{
N. Džinić ${ }^{1}$, Đ. Okanović ${ }^{2}$ M. Jokanović ${ }^{1}$, T. Tasić ${ }^{2}$, V. Tomović ${ }^{1}$, P. \\ Ikonić$^{2}$, S. Filipović ${ }^{2}$ \\ ${ }^{1}$ Faculty of Technology, University of Novi Sad, Bulevar Cara Lazara 1, 21000 Novi Sad, Serbia \\ ${ }^{2}$ Institute for Food Technology, University of Novi Sad, Bulevar cara Lazara 1, 21000 Novi Sad, \\ Serbia \\ Corresponding author: natadzin@uns.ac.rs \\ Original scientific paper
}

\begin{abstract}
The aim of this paper was to investigate the carcass and breast meat (nutritional, technological and sensory) quality of chickens (line ROSS 308) fed extruded corn. It was concluded that a diet with extruded corn increases chilled carcass weight and the share of breast meat in chilled carcass. Also, the breast meat of experimental group contains more protein and less free fat comparing to the control group. Based on the parameters and criteria for defining the quality of chicken breast meat $\left(\mathrm{pH}_{\mathrm{u}}\right.$ and $\left.L^{*}\right)$ revealed that the meat of both groups averagely corresponded to PSE quality. According to results of sensory analyzes cooked breast meat of experimental group had significantly $(\mathrm{P}<0.05)$ preferable juiciness and tenderness.
\end{abstract}

Key words: feeding, extruded corn, carcass and meat quality

\section{Introduction}

Traditionally, the term 'meat quality' covers inherent properties of meat decisive for the suitability of the meat for eating, further processing and storage including retail display. Consequently, quality is now to be considered as complex and multivariate property of meat, which is influenced by multiple interacting factors including the conditions under which the meat is produced. Feeding strategy is the management factor which is most actively used as a quality control tool in the production of meat and in relation to improvement and/or control of performance, animal welfare, safety, nutritional value, and eating and technological quality (Andersen et al., 2005). In the domestic production of forage mixtures, the corn has the leading position compared to other cereals, because of high energy contents $(16.2 \mathrm{MJ} / \mathrm{kg})$, starch, comparably big contents of oil and low level of cellulose (Bekrić, 1999). Proper thermal process provides the reduction of thermo labile antinutrients contents, to an acceptable level, and increases digestibility of 
some nutrients (protein, oil, carbohydrates), as well as the improvement of sensory features and the microbiological quality of the final product (Kormanjoš et al., 2007). Parallel with the reduction of antinutrients contents it is necessary to preserve nutritionally valuable thermo labile components, so the thermal process requires a compromise between the two efforts.

New technologies used to increase the nutritional value of feed are: toasting, hydrothermal refinement, micronisation, microwave treatment, bielectrical heat treating (Marsman et al., 1998). In Serbia the most often used process are extrusion and hydrothermal process (Sakač et al., 2001; Filipović et al. 2008).

Determination of carcass and meat quality includes two main parts the definition of indicators for expressing the individual characteristics of quality and quantification of the inherent characteristics in relation to the overall quality. Quality rating is more complete, if it is tested and defined by larger number of properties (Joksimović, 1977). Moisture, protein, fats, free amino acids and fatty acids are the most important components of meat and their qualitative and quantitative ratio determines the quality, i.e. nutritional value of meat (Rašeta and Dakić, 1994). Technological meat quality traits $(\mathrm{pH}$, water holding capacity, colour, cooking loss) are particularly important for industrial production and meat processing. Sensory properties: appearance, colour, texture, juiciness, aroma and taste are the most important characteristics in terms of consumers.

The aim of this study was to determine the carcass and breast meat quality (nutritional, technological and sensory) of chickens fed with extruded corn.

\section{Materials and Methods}

The experiment was carried on 3000 chickens, hybrid ROSS 308. Chickens were divided in two groups, control group (C) and experimental group (I) and fed under the same conditions in the period of 49 days. In the experimental group (I) corn was replaced with extruded corn. During whole chicken growing period water and feed were ad libitum. After growing and $12 \mathrm{~h}$ starving period, 10 chickens (female) from each group were slaughtered and processed by bloodletting, scalding, plucking and evisceration and chilled. Then chickens carcasses "ready to grill" from each group were cut in the basic anatomical parts (SFRY 1/81 and 51/88). Cutting and deboning of breast was applied in order to determine the breast meat yield and nutritive, technological and sensory quality of meat. Basic chemical composition of meat was estimated by determination of moisture (JUS ISO 1442 1997), protein (JUS ISO 937 1991), free fat (JUS ISO 1443 1997) and total ash (JUS ISO 936 1998) contents. Technological quality was evaluated by determinations of $\mathrm{pH}_{\mathrm{u}}$, and colour $\mathrm{u}$. Meat $\mathrm{pH}$ value was determined 24 hours post mortem (p.m.) using portable pH-meter ULTRA X. Breast meat colour was determined on the fresh cross section 24 hour p.m. using Minolta Chroma Meter CR-400, and colour characteristics were presented in u CIE $L^{*} a^{*} b^{*}$ system 
(lightness $L^{*}$, redness and greenness - $a^{*}$, yellowness and blueness - $b^{*}$ ) (Robertson, 1977). The samples (breast meat) were cooked in the convection air oven at $175^{\circ} \mathrm{C}$ for $45 \mathrm{~min}$. After cooking, samples were cooled at room temperature for $1 \mathrm{~h}$ and then analyzed for sensory characteristics. Five trained panellists, experienced in the sensory evaluation of various meat products were employed. The panellists recorded descriptive sensory evaluations. The structured linear scales were coded on a seven-point basis. Attributes included odour $(1=$ unpleasant, $7=$ extremely pleasant $)$, taste $(1=$ unpleasant, $7=$ extremely pleasant $)$, tenderness $(1=$ very firm, $7=$ very soft $)$, and juiciness $(1=$ very dry, $7=$ very juicy). All data are presented as mean values. Analysis of variance (Duncan test) was used to test the hypothesis about differences among obtained results. The software package STATISTICA 8.0 (STATISTICA 8.0, 2008) was used for analysis.

\section{Results and Discussion}

Examination of carcass quality (Table 1) of control and experimental group shown that greater weight (1966.9 g) of cold carcass "ready to grill" was in experimental group than in control (1859.0 g), but difference was not significant ( $\mathrm{P}$ $>0.05)$. Measured masses of chilled carcasses ,, ready to grill“" were larger than the results of Petričević et al. (2011) for female chickens of Ross 308 hybrid line, what could be attributed to the prolonged fattening period of 49 days. Greater breast weight (696.6 g) and whole leg weight (569.2 g), the most important parts of the carcass, were found in chickens of experimental group. The differences between the breast and whole leg weight of control and experimental group were not significant $(\mathrm{P}>0.05)$. Average values of back and wings weight were lower in chicken carcasses from experimental group. Again, weight of abdominal fat was lower $(31.2 \mathrm{~g})$ in chicken carcasses from experimental group.

Table 1. Mean values of results obtained by cutting of carcasses on main parts chickens of control and experimental groups

\begin{tabular}{|c|c|c|c|c|c|c|}
\hline Group & $\begin{array}{c}\text { Chilled carcass } \\
\text { mass } \\
(\mathrm{g})\end{array}$ & $\begin{array}{c}\text { Breast } \\
\text { mass } \\
(\mathrm{g})\end{array}$ & $\begin{array}{c}\text { Mass of } \\
\text { whole leg } \\
(\mathrm{g})\end{array}$ & $\begin{array}{c}\text { Mass of } \\
\text { back portion } \\
\text { and tail end } \\
(\mathrm{g})\end{array}$ & $\begin{array}{c}\text { Mass of } \\
\text { wings } \\
(\mathrm{g})\end{array}$ & $\begin{array}{c}\text { Mass of } \\
\text { abdominal } \\
\text { fat } \\
(\mathrm{g})\end{array}$ \\
\cline { 2 - 7 } & $\mathrm{X} \pm \mathrm{SD}$ & $\mathrm{X} \pm \mathrm{SD}$ & $\mathrm{X} \pm \mathrm{SD}$ & $\mathrm{X} \pm \mathrm{SD}$ & $\mathrm{X} \pm \mathrm{SD}$ & $\mathrm{X} \pm \mathrm{SD}$ \\
\hline $\mathrm{C}$ & $1859.0 \pm 220$ & $657.6 \pm 93$ & $528.2 \pm 63$ & $412.4 \pm 44$ & $217.6 \pm 24$ & $35.6 \pm 6$ \\
\hline $\mathrm{I}$ & $1966.9 \pm 79$ & $696.6 \pm 56$ & $569.2 \pm 27$ & $433.2 \pm 24$ & $236.0 \pm 11$ & $31.2 \pm 8$ \\
\hline Assessment of significance \\
\hline \multicolumn{7}{|l|}{ Group } \\
\hline
\end{tabular}


Chicken breast (Table 2) from experimental group had higher $(\mathrm{P}>0.05)$ $(540.8 \mathrm{~g})$ meat weight, share of muscle in breast weight $(77.5 \%)$ and share of breast weight $(27.4 \%)$ in chilled carcass.

Table 2. Mean values of muscle breast weight (g), share (\%) of muscle in breast and share (\%) of breast muscle in chilled carcass of control and experimental group

\begin{tabular}{|c|c|c|c|}
\hline \multirow[t]{2}{*}{ Group } & $\begin{array}{l}\text { Muscles breast weigh } \\
(\mathrm{g})\end{array}$ & $\begin{array}{c}\text { Share of muscle in } \\
\text { breast }(\%)\end{array}$ & $\begin{array}{l}\text { Share of breast muscle in } \\
\text { chilled carcass }(\%)\end{array}$ \\
\hline & $\mathrm{X} \pm \mathrm{SD}$ & $\mathrm{X} \pm \mathrm{SD}$ & $\mathrm{X} \pm \mathrm{SD}$ \\
\hline $\mathrm{C}$ & $501.8 \pm 81.7$ & $76.1 \pm 1.9$ & $26.9 \pm 1.3$ \\
\hline I & $540.8 \pm 60.8$ & $77.5 \pm 3.3$ & $27.4 \pm 2.3$ \\
\hline \multicolumn{4}{|c|}{ Assessment of significance } \\
\hline Group & $\mathrm{P}>0.05$ & $\mathrm{P}>0.05$ & $\mathrm{P}>0.05$ \\
\hline
\end{tabular}

The determination of basic chemical composition of chicken breast meat (Table 3) shown lower water (73.66\%) and protein (22.58\%) content in breast meat from control group of chickens. Further, it can be seen from the same table that the free fat content $(2.42 \%)$ was higher in breast meat of the control group comparing to experimental group $(1.40 \%)$. The results are consistent with those obtained by the authors Pavlovski and Palmin (1973), Perić et al. (1984), Džinić (1991), Džinić et al. (2009) and Kovačević (2001) confirming that chicken meat contains more protein $(23 \%)$ than other types of meat and less fat $(1-5 \%)$, and that can be considered as dietetic foods.

Table 3. Basic chemical composition and $\mathrm{pH}$ value of chicken breast meat

\begin{tabular}{|c|c|c|c|c|c|}
\hline Group & Moisture (\%) & Protein (\%) & Free fat (\%) & Total ash (\%) & $\mathrm{pH}_{\mathrm{u}}$ \\
\hline $\mathrm{C}$ & $73.66 \pm 0.1$ & $22.58 \pm 0.3$ & $2.42 \pm 0.3$ & $1.24 \pm 0.0$ & $5.67 \pm 0.1$ \\
\hline $\mathrm{I}$ & $74.04 \pm 0.3$ & $23.35 \pm 0.3$ & $1.40 \pm 0.4$ & $1.20 \pm 0.0$ & $5.71 \pm 0.1$ \\
\hline \multicolumn{5}{|l|}{ Assessment of significance } \\
\hline Group & $\mathrm{P}>0.05$ & $\mathrm{P}>0.05$ & $\mathrm{P}>0.05$ & $\mathrm{P}>0.05$ & $\mathrm{P}>0.05$ \\
\hline
\end{tabular}

The study of technological properties of breast meat (Table 3) showed that the average $\mathrm{pH}_{\mathrm{u}}$ value in experimental group was 5.71. Based on $\mathrm{pH}_{\mathrm{u}}$ values, as quality parameter and based on quality criteria (Ristić, 1981; Barbut et al., 2005) $5.7<\mathrm{pH}_{\mathrm{u}}<6.1$ breast meat of experimental groups was "normal" - (red-pink, firm, dry) quality. On the other hand, based on the same criteria breast meat of control group was PSE quality. In the Table 4 it can be seen that on average breast meat of control group with lighter $\left(L^{*}=56.33\right)$, comparing to experimental group $\left(L^{*}=\right.$ 53.91) but this difference was not significant $(\mathrm{P}>0.05)$. Based on the brightness parameter $\left(L^{*}\right)$ and criteria (Qiao et al., 2001; Lara et al., 2003) for PSE chicken 
meat quality $\left(L^{*}>52\right)$ meat from control and experimental groups were, on average, PSE quality. Furthermore, the average share of red colour $\left(a^{*}\right)$ in chicken breast meat of control group was significantly $(\mathrm{P}<0.05)$ higher than in experimental group.

Table 4. Colour and sensory characteristics of chicken breast meat

\begin{tabular}{|c|c|c|c|c|c|c|c|}
\hline \multirow{2}{*}{ Group } & \multicolumn{3}{|c|}{ Colour characteristics } & \multicolumn{4}{|c|}{ Sensory characteristics } \\
\hline & $L^{*}$ & $a^{*}$ & $b^{*}$ & Odour & Taste & Juiciness & Tenderness \\
\hline & 56.37 & $3.37^{\mathrm{a}}$ & 7.27 & 6.50 & 6.25 & $4.71^{b}$ & $5.71^{\mathrm{b}}$ \\
\hline $\mathrm{C}$ & \pm 3.0 & \pm 0.9 & \pm 1.6 & \pm 0.0 & \pm 0.0 & \pm 0.1 & \pm 0.1 \\
\hline I & $\begin{array}{l}53.91 \\
\pm 3.3\end{array}$ & $\begin{array}{l}1.92^{\mathrm{b}} \\
\pm 0.8\end{array}$ & $\begin{array}{r}6.88 \\
\pm 2.5\end{array}$ & $\begin{array}{r}6.42 \\
\pm 0.1\end{array}$ & $\begin{array}{r}5.96 \\
\pm 0.2\end{array}$ & $\begin{array}{l}4.96^{\mathrm{a}} \\
\pm 0.1\end{array}$ & $\begin{array}{l}5.88^{\mathrm{a}} \\
\pm 0.0\end{array}$ \\
\hline \multicolumn{8}{|c|}{ Assessment of significance } \\
\hline Group & $\mathrm{P}>0.05$ & $\mathrm{P}<0.05$ & $\mathrm{P}>0.05$ & $\mathrm{P}>0.05$ & $\mathrm{P}>0.05$ & $\mathrm{P}<0.05$ & $\mathrm{P}<0.05$ \\
\hline
\end{tabular}

Result of sensory evaluation of cooked breast meat samples of control and experimental group are presented in the Table 4. The odour and taste of chicken cooked breast meat from control (C) and experimental group (I) were averagely evaluated as "very good" (Table 4). On the other hand, juiciness and tenderness were averagely evaluated as "good" and "very good" and samples of experimental group had significantly $(\mathrm{P}<0.05)$ better marks for these attributes.

\section{Conclusion}

The diet with extruded corn resulted in increased weight of chilled carcass, higher share of breast meat in chilled carcass, higher protein and reduced free fat content in breast meat $(\mathrm{P}>0.05)$, comparing to control group. Additionally, it was found that the technological quality of breast meat of the control and experimental groups, according to parameters and criteria for quality estimation $\left(\mathrm{pH}_{\mathrm{u}}, L^{*}\right)$, averagely corresponds to PSE meat quality. According to results of sensory analyzes cooked breast meat of experimental group had significantly $(\mathrm{P}<0.05)$ preferable juiciness and tenderness.

\section{Acknowledgment}

The research has been conducted as a part of a project "The research of modern biotechnological methods in feed production in order to increase competitiveness, food quality and safety" financed by the RS Ministry of Education and Science, No 46012. 


\title{
Kvalitet trupa i mesa grudi brojlera hranjenih ekstrudiranim kukuruzom
}

\author{
N. Džinić, Đ. Okanović, M. Jokanović, T. Tasić, V. Tomović, P. Ikonić, S. Filipović
}

\section{Rezime}

U ovom radu je ispitan kvalitet trupa i nutritivni, tehnološki i senzorni, kvalitet mesa grudi pilića hranjenih ekstrudiranim kukuruzom. Ispitivanja su obavljena na pilićima hibridne linije Ross 308. Zaključeno je da ishrana sa ekstrudiranim kukuruzom utiče na povećanje mase ohlađenog trupa i veći udeo mesa grudi u ohlađenom trupu $(\mathrm{P}>0.05)$. Takođe, meso grudi eksperimentalne grupe sadrži više proteina i manje slobodne masti u odnosu na $(\mathrm{P}>0.05)$ meso kontrolne grupe. Na osnovu parametara i kriterijuma za definisanje kvaliteta mesa grudi pilića $\left(\mathrm{pH}_{\mathrm{k}} \mathrm{i} L^{*}\right)$ utvrđeno je da je meso obe ispitane grupe prosečno BMV kvaliteta. Rezultati senzorne analize ukazuju da je toplotno obrađeno meso eksperimentalne grupe značajno bolje $(\mathrm{P}<0.05)$ sočnosti i nežnosti.

\section{References}

ANDERSEN H.J., OKSBJERG N., YOUNG J.F., THERKILDSEN M. (2005): Feeding and meat quality - a future approach. Meat Science, 70, 543-554.

BARBUT S., ZHANG L., MARCONE M. (2005): Effects of pale Normal and Dark Chickens Poultry Breast Meat on Microstructure Extracable Proteins and Cooking of Marinated Fillets. Poultry Science, 84, 797-802.

BEKRIĆ V. (1999): Industrijska proizvodnja stočne hrane, Beograd

DŽINIĆ N. (1991): Uticaj sintetskih aminokiselina na prinos i kvalitet pilećeg mesa, Magistarski rad, Univerzitet u Novom Sadu.

DŽINIĆ N., TOMOVIĆ V., PETROVIĆ LJ., JOKANOVIĆ M., FILIPOVIĆ S. SAVKOVIĆ T. (2009): Kvalitet trupa i mesa grudi brojlera hranjenih različito obrađenim kukuruznim stočnim brašnom. Glasnik hemičara i tehnologa Republike Srpske, 2, 127-130.

FILIPOVIĆ S., KORMANJOŠ Š., SAKAČ M., ŽIVANČEV D., FILIPOVIĆ J., KEVREŠAN Ž. (2008): Tehnološki postupak ekstrudiranja kukuruza. Savremena poljoprivreda, 57, 3-4, 144-148.

JOKSIMOVIĆ J. (1977): Osnovi kontrole i upravljanja kvalitetom u proizvodnji hrane. Privredni pregled, Beograd

JUS ISO 1442 (1997): Meso i proizvodi od mesa - Određivanje sadržaja vode. 
JUS ISO 1443 (1997): Meso i proizvodi od mesa - Određivanje sadržaja slobodne masti.

JUS ISO 936 (1998): Meso i proizvodi od mesa - Određivanje ukupnog pepela. JUS ISO 937 (1991): Meso i proizvodi od mesa - Određivanje sadržaja azota.

KORMANJOŠ Š., FILIPOVIĆ S., PLAVŠIĆ D., FILIPOVIĆ J. (2007): Uticaj ekstrudiranja na higijensku ispravnost hraniva, Savremena poljoprivreda, 5-6, 143146.

KOVAČEVIĆ D. (2001): Kemija i tehnologija mesa i ribe. Prehrambeno tehnološki fakultet, Osijek.

LARA J.A.F., NEPOMUCENO A.L., LEDUR M.C., IDA E.I., SHIMOKOMAKI, M. (2003): Chicken PSE (Pale, Soft, Exudative) meat. Mutations in the ryanodine receptor gene. Proceedings of $49^{\text {th }}$ International congress of meat science and tehnology, $2^{\text {nd }}$ Brazilian congress of meat science and tehnology, 79-81.

MARSMAN G.J.P., GRUPPEN H., GROOT J., DE VORAGEN A.G.J (1998): Effect of toasting end extrusion at different shearl levels on soy protein interactions. J. Agr. Food Chem., 46, 7, 2770-2777.

PAVLOVSKI V.A., PALMIN J.E. (1973): Biohemija mjasa. Piščepromizdat, Moskva.

PERIĆ V., KARAN-ĐURĐIĆ S, DAKIĆ, M. (1984): Hemijski sastav i biološka vrednost belog i crvenog mesa brojlera različitih klasa. Tehnologija mesa, 7-8, 237242.

PETRIČEVIĆ V., PAVLOVSKI Z., ŠKRBIĆ Z., LUKIĆ M. (2011): The effect of genotype on production and slaughter properties of broiler chickens. Biotechnology in Animal Husbandry, 27, 2, 171-183.

Pravilnik o kvalitetu mesa pernate živine (1981): Službeni list SFRJ br. 1/8 i $51 / 88$.

QIAO I.M., FLETCHER D. L., SMITH D. P., NORTCHET J. K. (2001): The effects of broiler breast meat color on $\mathrm{pH}$ moisture, water-holding capacity and emulsification capacity. Poultry Science, 80, 676-680.

RAŠETA J., DAKIĆ M. (1994): Higijena mesa, Veterinarski fakulte, Beograd.

RISTIĆ M. (1981): Faktori koji utiču na kvalitet mesa brojlera: trajanje tova, transport i hlađenje. Tehmologija mesa, 7-8, 227-235.

ROBERTSON A.R. (1977): The CIE 1976 Color-Difference Formulae. Color Research Applied 2, 7-10 .

SAKAČ M., FILIPOVIĆ S., RISTIĆ M. (2001): Proizvodnja punomasnog sojinog griza postupkom suve ekstruzije. PTET, 5, 1-2, 64-68

STATISTICA (Data Analysis Software System), v.8.0. (2008): StatSoft, Inc, Tulsa, OK, USA (http://www.statsoft.com/ 